\title{
THREE MILLENNIA OF CHINESE POETRY
}

\author{
TRÊS MILÊNIOS DE POESIA CHINESA
}

Anabela Fong Keng Seng ${ }^{1}$

\begin{abstract}
A poesia tem uma história de milhares de anos na China e pode-se dizer que é a jóia brilhante na coroa da literature chinesa, ocupando uma proporção maior em sua história. Originando-se de cantos folclóricos, a poesia chinesa produziu um grande número de exemplos brilhantes, desde a dinastia Zhou Dynasty ocidental (1046-771 BC) até o período Chunqiu [primavera e outono] (770-476 BC). A China tem mantido, desde os tempos antigos, uma tradição de educação em poesia, que é usada para educar as pessoas e estimular sua inteligência. Através da leitura, estudo e escrita de poesia, é possível instruir e cultivar o caráter de jovens alunos, assim como promover o pensamento criativo, dialética lógica e consciência humanística de crianças. Além disso, aprender e escrever poesia tem o efeito de cultivar o próprio temperamento, permitindo que pessoas de todos os estratos sociais, ocupações profissionais e idades limpem e purifiquem suas mentes. O reino da poesia tem o mesmo efeito de acalmar a alma da crença religiosa. Este artigo mostra os destaques de três milênios de poesia chinesa para leitores ou estudiosos cuja língua nativa não é o chinês.
\end{abstract}

Keywords: Chinese Poetry; History

\begin{abstract}
Poetry has a history of thousands of years in China and can be said to be the shining jewel in the crown of Chinese literature, occupying a major proportion in her history. Having originated from folk songs, the Chinese poetry has produced a large number of brilliant examples from the Western Zhou Dynasty (1046-771 BC) to the Chunqiu (Spring and Autumn) Period (770-476 BC). China has, since ancient times, maintained a tradition of education in poetry, which is used to educate the people and arouse their intelligence. Through the reading, studying and writing of poetry, it is possible to instruct and cultivate the character of young pupils, as well as to promote children's creative thinking, logical dialectics and humanistic consciousness. In addition, reciting, learning and writing poetry has the ability to cultivate one's temperament, allowing people of all social strata, professional occupation and age to cleanse and purify their minds. The realm of poetry has the same effect of calming the soul as religious belief. This article shows the highlights of three millennia of Chinese poetry to the readers or scholars whose native language is not Chinese.
\end{abstract}

Palavras-chave: poesia chinesa; História

Poetry has a history of thousands of years in China and can be said to be the shining jewel in the crown of Chinese literature, occupying a major proportion in her history. Having originated from folk songs, the Chinese poetry has produced a large number of brilliant examples from the Western Zhou Dynasty (1046-771 BC) to the Chunqiu (Spring and Autumn) Period (770-476 BC).

The Classic of Poetry (Chinese: 詩經 Shījīng), also Shijing or Shih-ching, translated as the Book of Odes or the Book of Songs, is the earliest collection of Chinese poetry, comprising 305 poems written from the $11^{\text {th }}$ to $6^{\text {th }}$ centuries BC and selected by Confucius from among a large amount of existing works. The chapters in the Classic of Poetry not only relate to the feast, worship, and epic but also reflect the ancient Chinese society and public feelings, laying a solid

\footnotetext{
${ }^{1}$ Universidade de Macau - Macau, China; https://orcid.org/0000-0001-8495-9128; anabelasaramago888@gmail.com
} 
humanistic foundation and artistic heritage for later literary creations (Fong Keng Seng, 2019, p. 100-124).

With syntactic parallelism, most of the lines in Poetry are written in 4 Chinese characters per line (a four-syllable meter), while longer poems are generally divided into similarly structured stanzas. The Classic of Poetry has been studied and memorized by scholars in China and neighboring countries over two millennia. Its rhyme patterns have also been analyzed in the study of Old Chinese phonology and its verses are also a rich source of chengyu (fourcharacter classical idioms) that are still a part of learned discourse and even everyday language in modern Chinese.

The Classic of Poetry is divided into three parts: "Airs of the States", "Court Hymns" and "Eulogies", all of which can be accompanied by music. The "Airs of the States" are generally lyrics and ancient folk songs which talk about love, courtship, military life, farming and housework, as well as political satire. Most of the poems of "Court Hymns" were used by the aristocracies to worship gods, venerate their ancestors and to pray for good harvests, while some are expressing dissatisfaction with the political reality. "Eulogies" contains praises, hymns, or eulogies sung at spirit sacrifices. Amongst all the works, the love poems are particularly moving, such as: Green, green the reed / Dew and frost gleam / Where's she I need / Beyond the stream /...... Upstream I go / The way does wind / Downstream I go / She's far behind (The Reed, translated by $\mathrm{Xu}$ Yuanchong) ${ }^{2}$.

During the late Warring States Period (476-221 BC), the southern state of Chu witnessed the creation of a new and unique style of poetry - the Chu Ci, variously translated as Verses of $\mathrm{Chu}$ or Songs of Chu. The poems of $\mathrm{Chu} C \mathrm{C}$ have varying metrics, most with six or seven Chinese characters per line. The founder and main poet of $C h u C i$ was Qu Yuan (340-278 BC), an aristocrat of the Kingdom of $\mathrm{Chu}$, who used this Chu style for creating the immortal poems such as Li Sao ("Encountering Sorrow"), Jiu Ge ("Nine Songs") and Jiu Zhang ("Nine Chapters"), thus becoming the first great poet in the history of Chinese literature, and he is revered as the God of Chinese Poetry.

Qu Yuan's masterpiece Li Sao, a 2890 character-long poem, is the most magnificent epic in the history of ancient Chinese poetry, as well as the longest example of political Romanticism in poetry from ancient times and acclaimed as the literary representative of $\mathrm{Qu}$ Yuan's high moral conduct and patriotism. Using his personal life, virtues, and values as a starting point, the poet expresses his pain of being persecuted by treacherous officials, while insisting on upholding his ideal of "benevolent politics", loving the people and criticizing the grim reality, ultimately preferring to take his own life rather than coexist with corrupt forces. He continues to tell his story of exile in the Li Sao ("Encountering Sorrow"): "My true integrity defamed / Gave ear to slander / high his anger flamed"3.

During his days of exile, Qu Yuan grew orchids (symbol of integrity) and wrote Li Sao. Upon hearing the news of the Chu capital defeated by the Kingdom of Qin, Qu Yuan finally committed suicide by drowning himself into the Miluo River with a heavy rock. When the locals learned the death of Qu Yuan, they raced out in boats, beating drums and splashing the wooden paddles to scare off evils and fish, and throwing sticky rice balls into the river to appease the dragons, and to entice the fish to eat the rice instead of Qu Yuan's body. So it is traditionally considered as the origin of the remembrance of Qu Yuan's death that the Dragon boat Festival are held.

\footnotetext{
2 原文為：“萧臀蒼蒼, 白露為霜。所謂伊人, 在水一方。”劉毓慶, 李蹊譯注: 《詩經上 國風》, 北 京：中華書局, 2011年, 第314頁（Liu Yuqing; Li Xi, 2003, p. 314）譯文見：許淵沖英譯；姜勝章編校. 《詩經》, 長沙：湖南出版社, 1993年, 第236頁 (Xu Yuanchong (English translator), Jiang Shengzhang (editor), 1993, p. 236)

3 屈原诗原文為：“荃不查餘之中情兮, 反信堍而齋怒。” (Qu Yuan, David Hawkes, 1985, p. 69)
} 
The emergence of $C h u C i$ represents the development of Chinese poetry to a higher stage, evolving from collective folk songs to independent creations by individual poets. The Classic of Poetry and the $\mathrm{Chu} C \mathrm{C}$ are the two major sources of the development of later generations of poetry. They are also seen as a precedent of Feng Sao (Literary Excellence) in History of Literature, blending the best traditions of both Realism and Romanticism in ancient Chinese poetry and standing as a model for ages and ages.

In the early period of the Han Dynasty (BC206-220), it appeared amongst the common people a genre of sung folk poetry, the Yuefu. Originally meaning "Music Bureau", the term "Yuefu" was later applied to the poems collected and edited by that imperial governmental institution. Yuefu folk music in Han Dynasty inherits the traditional realistic approach of the folk poems of the Classic of Poetry, with a lively style that is both popular, accessible and perfect for narration. The lines of the Yuefu are either of uneven length or fixed at five characters per line. Amongst the best works of Yuefu folk poetry are the "Mo Shang Sang"4 ("Mulberry by Road") and "Kongque Dong Nan Fei" ("The Peacocks Fly to the South and the East"). Both are also representative works of narrative poetry, the later one being the longest narrative poem in the genre.

The Nineteen Old Poems from the late years of the Eastern Han Dynasty are a short collection of poems written by poor literati. The immense value of these nineteen poems lies in their sentimental power, both soft and subtle, and channeled through sober and refined writing. Notable examples are the poetry of Cao Cao (c. 155-220) and his sons Cao Pi and Cao Zhi, as well as that of the "Seven Scholars of Jian'an". As one of the central figures of the Three Kingdoms period, Cao Cao was a warlord and the penultimate grand chancellor of the Eastern Han dynasty who rose to great power in the final years of the dynasty. The group "Seven Scholars of Jian'an" is famous for their use of five-character lines, while Cao Cao preferred writing poetry with four characters per line. Cao Pi's "Yan Ge Xing" ("Song of Yan") presents a seven-character line style.

The Three Kingdoms (220-280) and Western Jin Dynasty (265-317) periods did not leave us many poems, apart from those of poets like Ji Kang, while the Eastern Jin Dynasty (317-420) produced a large number of brilliantly lyrical works. Among the most famous poets, Tao Yuanming was praised by later generations for his fresh poetic style.

The poetry style from the Northern Dynasties was simple and upright, with "Mulan Ci" ("The Ballad of Mulan") as the best example. It recounts the story of Mulan, a girl who goes to war in place of her father. This period also produced a vast quantity of poetry criticism, such as Zhong Rong's Shi Pin ("Ranking Poetry"), Liu Xie's Wen Xin Diao Long ("The Literary Mind and the Carving of Dragons") and Xiao Tong's Wen Xuan ("Selections of Refined Literature"), all of which are highly influential works on Chinese literary aesthetics and had a huge impact on the content, ideas, and appreciation of poetry. By the same time, literati from the Southern Dynasties first put forward the applied rules of tonal euphony known as "Si Sheng Ba Bing" ("four tones and eight defects"), which had a considerable impact on the creation and appreciation of poetry going forward.

In early period of the Tang Dynasty (618-907), the Chinese poetry arose a gradual formation of a number of specific forms, such as Jueju (Chinese quatrain), Lüshi and the Pailü which are the most important poetic forms of classical Chinese poetry, also known as "regulated verse" and can be called Jintishi (modern form poetry) in order to be commensurate with ancient style poetry. Jueju poems can be quatrains or compose of one or two pairs of couplets, with

\footnotetext{
4 (宋) 郭茂倩編, 《樂府詩集》, 北京: 中華書局, 1979, 第410頁。

5 (南朝梁) 鐘喍著, 周振甫譯註, 《詩品譯註》, 北京：中華書局, 1998。

6 (南朝梁) 劉妿思, 周振甫譯註, 《文心雕龍選譯》, 北京：中華書局, 1980。

7 (南朝梁) 蕭統, 《文選》, 北京：中華書局, 1977。
} 
each line consisting of five or seven syllables (four lines and each line has five or seven characters, with intermittent rhyme). The Jueju style was very popular from the Tang dynasty to Present. With the concept of "seeing the big through the small", many poets wrote on topics of a grand scale: love, philosophy, emotions, vast landscapes, history, religion, and so on.

Many people think that Lüshi is the extended form of Jueju. Actually, Jueju was derived from Lüshi with the adoption of the form of couplets. The Lüshi refers to an eight-line regulated verse form with lines made up of five or seven syllables (each line has five or seven characters, with intermittent rhyme). There are two forms of Lüshi: 1 . Wulü which is five-character and eight-line regulated verse (a form of regulated verse with eight lines of five characters each, with intermittent rhyme); 2. Qilü which is seven-character and eight-line regulated verse (a form of regulated verse with eight lines of seven characters each, with intermittent rhyme). As the extended form of Lüshi and expansion of the above-mentioned forms with more than eight lines, each poem of Pailï should be a multiple of four lines.

The Tang Dynasty is considered as the "Golden Age of Chinese Poetry", with Li Bai (701-762) and $\mathrm{Du} \mathrm{Fu} \mathrm{(712-770)} \mathrm{as} \mathrm{the} \mathrm{most} \mathrm{distinguished} \mathrm{poets.} \mathrm{The} \mathrm{first} \mathrm{one} \mathrm{has} \mathrm{been} \mathrm{granted}$ the epithet of Shi Xian ("poet-immortal"), and the latter that of Shi Sheng ("poet-sage"). The Anthology Three Hundred Tang Poems was the most popular anthology of classic poetry in China and its first edition was published in the $18^{\text {th }}$ century. In the same century, translations of Li Bai and Du Fu's poems began to appear in Europe. In the West, multilingual translations of these two transcendent poets' works continue to be made, including Portuguese, namely "Poemas de Du Fu" (2015), translated by António Graça de Abreu ${ }^{8}$ who described that was indeed a mission impossible.

Li bai was a genius gestated by prosperous Tang culture and his poems were models for celebrating the depth of nature, solitude, the pleasures of friendship, and the joys of drinking wine. One of his most famous poems "Jing Ye Si" ("Quiet Night Thought": Moonlight before my bed / Perhaps frost on the ground / Lift my head and see the moon / Lower my head and I miss my home $)^{9}$ is known to every Chinese who can read in the world. It is a poem written by a homesick soul, using simple language but bursting with artistic conception. As it is extremely easy to remember, it possesses the power to resonate with people's hearts. Handed down over thousands of years, it has become the most familiar classical poem for Chinese people.

While Li Bai's poetry is that of a genius, Du Fu's writings are concerned with the suffering of the common people. This poet writes about the hardships in the life of the common peasant with superb skill and artistic flair, which has granted him the admiration of people throughout generations. Next to Li Bai and Du Fu, Bai Juyi is also another master of Chinese poetry, with masterpieces such as "Chang Hen Ge" ("Song of Everlasting Regret") and Pi Pa Xing ("The Song of the Pipa Player"). During the later years of the Tang Dynasty, Du Mu and Li Shangyin made great achievements in poetry.

The period that goes from the late years of the Tang Dynasty to the Five Dynasties (907960) saw the gradual development of a new style of poetry, the Ci (a variation of Shi poetry that was, at first, accompanied by music; the later disappearance of the musical score left us only the poems themselves). The Song Dynasty (960-1279) witnessed huge achievements in Ci, with representative figures such as Ouyang Xiu, Su Shi, Liu Yong and Li Qingzhao (poetess). Su Shi was a very prolific poet, employing an elegant and unconventional style of language, as well as a natural and unrestrained writing that resulted in a great talent and bold pieces, namely "Lyrics to Remembering Your Charm - Remembrance of the Tale of the Crimson Cliff", but

\footnotetext{
8 杜甫著, António Graça de Abreu 譯, 《Poemas de Du Fu》（杜甫詩選），中國澳門：澳門特別行政區 文化局, 2015。

9 李白诗《靜夜思》: “床前明月光, 疑是地上霜。舉頭望明月, 低頭思故鄉。”
} 
also in graceful ones, such as "Water Melody - When will the moon be clear and bright?"10). Lu You was the most notable poet of the Southern Song Dynasty (1127-1279), as well as the most prolific in Chinese history, having produced about10,000 poems in 60 years.

The Song Dynasty was the Golden Age of Ci poetry. In the Yuan Dynasty (1206-1368), we see the appearance of $\mathrm{Qu}$ (another variation of Shi poetry), which could also be employed in performances of traditional Chinese drama. Guan Hanqing, Ma Zhiyuan, Bai Pu and Zheng Guangzu are called the Four Great Masters of Qu during the Yuan Dynasty. We can thus summarize that Tang Shi, Song $\mathrm{Ci}$, and Yuan Qu are the three major categories of Chinese classical poetry.

In modern times, the poet Feng Gangyi (1944-2019) has rivalled Lu You of Song Dynasty in composing 10,000 poems within 60 years. He was particularly adept at "orchid poetry", having been granted the title of "Orchid Poet". In his lifetime, Feng Gangyi has created 800 orchid poems by clever way of anthropomorphizing (i.e. by comparing orchids to various beauties and heroes). At the same time, he pioneered the use of long poems to write about Chinese history and world historical events. There are 43 epics of this kind, the longest of which is "The Glory of the Beijing Olympic Games"11, which describes the grand occasion of the 2008 Beijing Olympics. With a total of 3024 characters, this poem is the longest one in the history of Chinese poetry.

China has, since ancient times, maintained a tradition of education in poetry, which is used to educate the people and arouse their intelligence. Through the reading, studying and writing of poetry, it is possible to instruct and cultivate the character of young pupils, as well as to promote children's creative thinking, logical dialectics and humanistic consciousness. In addition, reciting, learning and writing poetry has the ability to cultivate one's temperament, allowing people of all social strata, professional occupation and age to cleanse and purify their minds. The realm of poetry has the same effect of calming the soul as religious belief (Fong Keng Seng, 2019, p. 138-139).

For thousands of years, ever since Qu Yuan, many patriotic poets with the people-based thoughts have composed a multitude of fine poems, infusing the deepest of feelings for the Motherland in the hearts of generations of Chinese. For example, Du Fu's verses "The fires of war lasting for two springs / a letter from home is worth ten thousand pieces of gold"12, and the famous verses written by the poets of the Song Dynasty, such as, Li Qingzhao's "While alive, be a great man among people / When you die, be a hero among ghosts" resist in a chariot / and even destroy the enemies' mountain with my footsteps / With the tremendous courage, I eat the invaders' meat when I am hungry / And drink the invaders' blood when I am thirsty" ", Lu You's "I know that there will be nothing left when people die / but I will still feel sad if I cannot witness the reunification of my motherland / When the armies of our Kingdom of Song retake the Central Plains / Do not forget to tell the spirit of your old father so, when you offer libations" 15 , Wen Tianxiang's "Who, since ancient times, can be not immortal? Let me die for my country and mark my loyalty in the pages of history"16.

Since the above-mentioned poems are written in Classical Chinese literary language and there are many strict rules on format and rhythm, it is quite difficult to translate them in foreign languages. Even if the meaning of the poems can be translated, it is inevitable that some images

\footnotetext{
10 苏轼词词牌《水調歌頭・明月幾時有》

${ }^{11}$ Feng Gangyi, 冯刚毅, 《冯兰海长诗选》, 澳门 : 澳门中华诗词学会, p. 112

12 杜甫诗原文為：“烽火連三月，家書抵萬金。”

13 李清照诗原文為：“生當作人傑, 死亦為鬼雄。”

${ }^{14}$ 岳飞诗原文為：“駕長車，踏破賀蘭山缺。壯志䬧餐胡虜肉，笑談渴飲匈奴血。”

15 陆游诗原文為：“死去元知萬事空，但悲不見九州同。王師北定中原日，家祭無忘告乃翁。”

16 文天祥诗原文為：“人生自古誰無死, 留取丹心照汗青。”
} 
will be lost in the translation, or there will be some differences in poetic mood or artistic merits between the source language and target language. As such, Modern Chinese Poetry appeared in the beginning of the $20^{\text {th }}$ century with the aim of making poetry more accessible to the common people. This Modern Poetry refers to the new genre of poetry being created since the May Fourth Movement (1919), which is characterized by being written in vernacular language, as well as by breaking the constraints of metrical verse and rhymes of classical poetry. Therefore, its writing style is free, flexible and unconstrained by a fixed format.

The first magazine experimenting with and advocating Modern Chinese Poetry was La Jeunesse (or "New Youth"), followed by publications such as "New Wave" ( Chinese: Xīncháo) and "Young China" (Chinese: Shàonián zhōngguó). Its advocates and early poets mainly include Hu Shi, Liu Bannong, Shen Yinmo, etc. The most famous poet of Modern Chinese Poetry is $\mathrm{Xu}$ Zhimo (or Changhsu Hamilton Hsu) and his best-known poem is Zaibie Kangqiao $^{17}$ ("Saying Goodbye to Cambridge Again") (1928) which can also be considered as the representative work of the famous Crescent Moon School.

While returning to China by boat after visiting Cambridge for the last time in the autumn of 1928 , the poet fully described in this poem the beauty of the scenery and his regret at leaving England. To commemorate Xu, in July 2008, a stone of white marble was installed at the Backs of King's College, Cambridge (near the bridge over the River Cam). The one translated by Guohua Chen was published in the University of Cambridge's $800^{\text {th }}$ anniversary book. Many Chinese can recite from memory the first paragraph of this poem: Softly I am leaving / Just as softly as I came / I softly wave goodbye / To the clouds in the western sky ${ }^{18}$.

A later-generation of poets influenced by contemporary Western poets and modernist imagist techniques has flourished in China in 1980s. They are defined as the Misty Poets (Chinese: Ménglóng Shīrén) since their idea and social commentary manifest itself through hermetic images and metaphors that resulted in the designation of "Misty Poetry" (Chinese: menglong shi). The Misty Poets reflect their subjective experience and individuality that ushered in a new era of artistic expression. The most influential poets of the Misty School include Bei Dao, Shu Ting, Yang Lian, Gu Cheng, Mang Ke, Xi Chuan, etc.

After the Misty Poetry School, Hai Zi (with the meaning "Son of sea" - the pen name of the Chinese poet Zha Haisheng) was the most celebrated poet in Mainland China especially with the new generations. He committed suicide by lying on the rail in Shanhaiguan Great Wall at the age of 25. He says he is influenced by the Chinese classics (The Classic of Poetry and $\mathrm{Qu}$ Yuan) but also Homer and Greek mythology, and his death is also regarded a symbol of the sacrifice of the agricultural civilization. Hai $\mathrm{Zi}$ is now one of the most widely read contemporary poets in Mainland China. Some of his lyric poetry have been set to songs, such as, "Facing the Sea, with Spring Blossom"19, with the description of an ideal location for a home overlooking the sea, which warm enough for flowers blooming in spring.

From 2019, since the most influential scholar-poet Gong Gang's has advocated the new poetic theory as Neo-Hsinglingism which is the inheritance and the transformation of the core conceptions of Hsingling School of the Ming and Qing Dynasties, Neo-Hsinglingism is not only practiced in the poem writing of the Seven-Sword-men Poetry School and their friends, but unleash new waves of poetic creation within the academic circles and the younger

\footnotetext{
17 徐志摩, 《徐志摩全集》, 天津 : 天津人民出版社, 2005。

18 徐志摩原文為：“輕輕地我走了, /正如我輕輕地來 ; / 我輕輕的招手, / 作別西天的雲彩。”徐志摩著;

顧永棣編. 《徐志摩全集 詩歌卷》, 杭州 : 浙江出版聯合集團; 浙江人民出版社, 2015年, 第218頁

(Xu Zhimo, Gu Yongdi (ed.) p. 218)

19 海子原文為: “面朝大海, 春暖花開。”海子著：《海子經典詩選》, 南京：江蘇鳳凰文藝出版社,

2019年，第2頁（Hai Zi, 2019, p. 2)
} 
generation with the impressive multi-erudition of the scholars who are in favour of this theory and its excellent academic potential. ${ }^{20}$

This new poetic theory relates to a lot of traditional Chinese poetic theories. The Hsinglingist poets in Ming and Qing Dynasties recognized that the idea of "expressing natural disposition and intelligence irrespective of any set rules" as their core belief in poetry writing, which is human nature and life awareness, driven by the Buddhist idea of "nature of mind", emphasizing the originality and lyricism and pursuing the natural flow of the romantic charm. However, the Neo-Hsinglingism advocates the great importance of epiphany and philosophical depth, like the subtle enlightenment sprung from the base of thorough understanding, long-time life experience, sudden inspiration, as well as the philosophical lyricism in poetry writing. That is to say, a poet must have poetic wisdom and a vision for his own soul, as is said by Plato. Gong Gang even indicated that "Better not to write any poem if lightening has not touched your hand" which is also the core spirit of the Seven Sword-Men Poetry School and NeoHsinglingism, just as his verses: "The stars all over the sky / Shake slightly and shine / Through darkness and trees / A heavy snow / Is falling / In the corner of memory".

\section{WORKS CITED:}

FONG, Keng Seng. Critical Essays on Western and Chinese Poetry and Poetic Art Education. Beijing: China Guangming Daily Publishing House, 2019.

HAI Zi. Classic Poems by Hai Zi. Nanjing: Jiangsu Phoenix Literature and Art Publishing House, 2019.

LIU Yuqing; LI Xi. The Book of Songs I. Airs of the States. Beijing: Zhonghua Book Company, 2003.

QU Yuan; HAWKES, David. The Songs of the South. Great Britain: Cox and Wyman Ltd, Reading, 1985.

XU Zhimo, GU Yongdi (edS.) The Complete Works of Xu Zhimo (Poetry). Hangzhou: Zhejiang Publishing United Group; Zhejiang people's publishing house, 2015.

XU Yuanchong (English translator), JIANG Shengzhang (ed.) The Book of Songs. Changsha: Hunan Press, 1993.

Anabela Fong Keng Seng is a visiting researcher of Research Centre for Humanities in South China at University of Macau, poetess and President of Macau Chinese Poetry Association. For further information see https://baike.baidu.com/item/\%E5\%86\%AF\%E5\%80\%BE\%E5\%9F\%8E

Submetido em 13/05/2020

Aprovado em 13/07/2020

\footnotetext{
${ }^{20}$ Poetry Hall Issue II, Gong Gang's What Are the Main Features of Neo-Hsinglingism? PP1-2
} 